\title{
文化財と高分子科学 一中尊寺の遺体で使われている絹を例に一
}

中尊寺金色堂（岩手県平泉町）に保存されている三体の遺体は藤原清衡, 基衡, 秀衡のもの である。これらの遺体が納められている棺の中にあった絹の ${ }^{13} \mathrm{C}$ 固体高分解能 $\mathrm{NMR}$ から， 絹 を構成しているアミノ酸のモル分率とスピン格子緩和時間を求め, それらと当時の気温（年輪 考古学による）とを比較し, 遺体は須弥檀の側から見て, 左から順に基衡, 清衡, 秀衡のもの であることを明らかにする。これは，現在お寺で採用されている帰属とは反対である。

\section{中條利一郎}

\section{1. はじめに}

この号は「高分子と文化」の特集である。そこで，ユネ スコの世界遺産についての話から始めるとしよう。世界遺 産は 1972 年に制定された世界遺産条約に基づいている。 この条約は, 正式には,「世界の文化遺産及び自然遺産の保 護に関する条約」と呼ばれていることからわかるとおり, 文化遺産として知られる「文化」に関係している。わが国 では，文化遺産などの保護に関しては，国内法のほうが優 れているという認識加ら, 当初, 世界遺産について冷淡と あいうべき態度だったが，それでは国際的に足並みがそろ わないということで, 現在, 文化, 自然, あわせて 13 件が 登録されており，さらに複数の遺産が暫定登録されてい る。後者の一つ, 平泉の文化遺産 (岩手県) が登録される 前に片付けておくべき問題について，高分子科学的に解明 された例について紹介する。

「我々はどこから来たのか, 我々は何者か, 我々はどこへ 行くのか」。ボストン美術館に所蔵されているゴーギャン の絵のタイトルである。私どあにとって根源的と屯いうべ きこれらの問いに答えるべく, 遺産に対して, 科学や工学 からの多くのアプローチが見られる。高分子科学に話を限 ると，遺産の保存や修復のために高分子材料を用いるの と, 遺産の特性を知るための高分子科学の手法を用いた解 析とに大別できる。この号では, 川野邊の展望が前者であ り，筆者のが後者である。

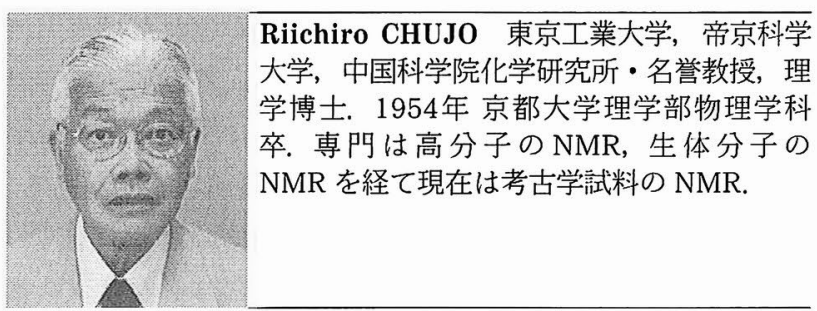

\section{2. 問題の所在}

平泉は奥州藤原氏が築いた文化遺産である。マルコ・ ポーロの東方見聞録に「チパングは, 東のかた，大陸から 千五百マイルの大洋中にある，とてあ大きな島である。(中 略）この国王の一大宮殿は，それこそ純金ずくめでできて いるのですぞ」り と書かれている。これが事実に基づいて いるのであれば，平泉の中尊寺金色堂以外には考えられな い。まだ，金閣寺も秀吉の黄金の茶室もつくられる前の記 述だからである。世界史的にも意義の大きいところと言え よう。

金色堂は図 1 に見られるとおり，美しい建造物であ

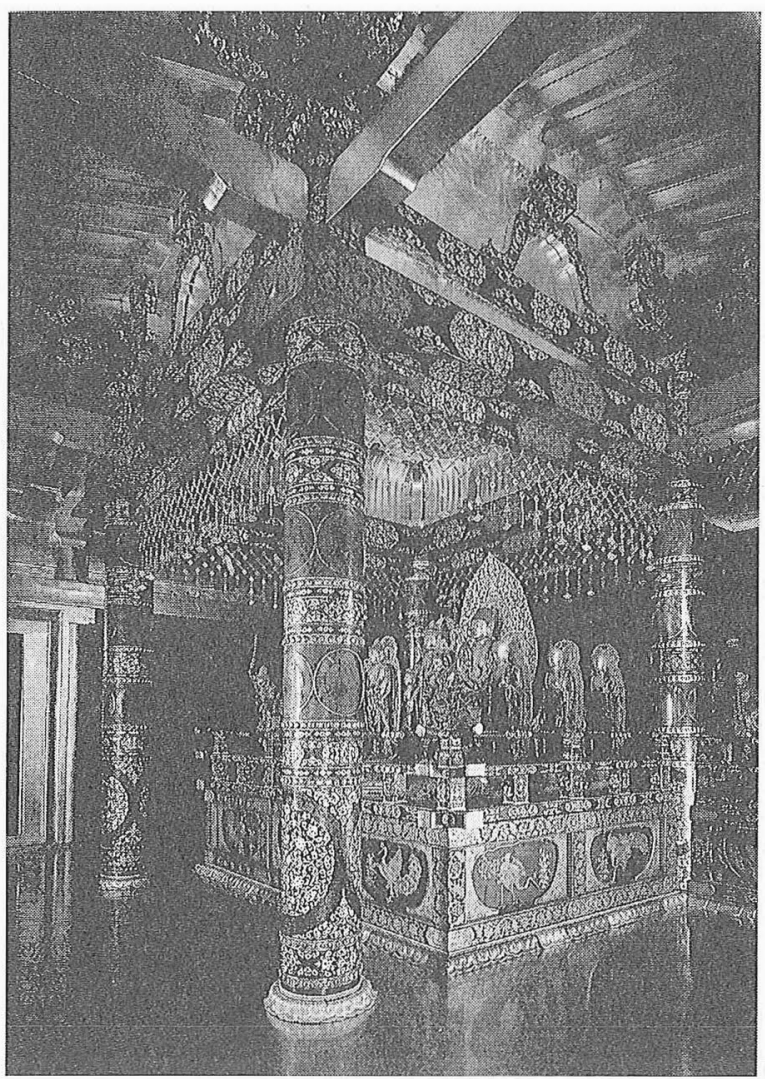

図 1 中尊寺金色堂（文献15 の加島 勝氏の論文より） 
る $^{15)}$ 。須弥檀は初代清衡, 二代基衡, 三代秀衡が死ぬたび に増設され，現在は三檀からなる31。そして，それぞれの檀 の下に一体ずつミイラが安置されている。中尊寺では, 信 仰の対象ということで, ご遺体と呼んでいる。ここでは遺 体之書くことにする。どの遺体が誰のものかという帰属に 関しては，鎌倉時代後期（14 世紀初頭）に書かれたあのと 考えられている「中尊寺経蔵文書」に「金色堂は三間四面, 中檀は阿弥陀の三尊, 清衡の建立なり, 左の檀は基衡の建 立なり，右の檀は本尊同じ，秀衡の建立なり」の記述があ $り^{4)}$, 左加ら順に基衡, 清衡, 秀衡之考えられる。問題は左 右といらのが, 須弥檀の側から見てのあのなのか, 捧む人 の側から見てのものなのかということである。1950（昭和 25）年に中尊寺之朝日新聞文化事業団とで調查が行われた が，それまでは須弥檀の側からの左右の定義が採用されて いた。わが国だけでなく，東アジアで広く採用されている 上位の側からの定義で, 素直に受け入れられる。ところが, この調査の際, 扯む人の側からの定義に置き換えられた。 まったく根拠がないというわけではないが，高分子科学か らの寄与ではないので，ここでは紹介しない。何分にも半 世紀以上も昔のことで, 関係のあった方々も一人を除いて は物故されており, 定義逆転の詳細は不明である。調查団 員の一人，物故された F 教授のご令息によると， M 博士の ッルの一声で決まったと $\mathrm{F}$ 教授は生前仰っていた由であ る。文献 4 でも，M博士執筆の章は自信に満ちた筆致で逆 転に対する主張が貫かれているのに対し，他の団員執筆の 章は歯切れの悪い筆致で，F 教授ご令息の記憶之符合す る。問題の所在は 1950 年のこの左右の定義が妥当が゙う かにある。

\section{3. 絹の ${ }^{13} \mathrm{C}$ 固体高分解能 $\mathrm{NMR}$}

1950 年の調查の際, 遺体に固着した絹をはがしたもの や，棺の内貼り，枕などの絹製品が保存されている。絹は 蚎から吐出されたときはフィブロインだけでなく，セリシ ンも含んでいるが, 精練されるとほとんどフィブロインだ けになる。言うまであなく, フィブロインはタンパク質で ある。DNA でコードされて重合するから，気温などの外 的条件によってアミノ酸組成は変わらないかと思いきや， そうであない。繊維だから, 結晶部分とアモルファス部分 からなる。結晶を構成するフィブロインは DNA でコード された一定の組成と順序であるのに対し，アモルファス部 分を構成するフィブロインには任意性がある5う。これに対 応して, DNAにも可変部分があることが知られている6。 それでは中尊寺の絹の ${ }^{13} \mathrm{C}$ 固体高分解能 NMR はどうか?

図 2 は三つの棺の中にあった絹の ${ }^{13} \mathrm{C}$ 固体高分解能 NMR スペクトルである7)。上から順に清衡, 基衡, 秀衡の 棺の中にあった絹のスペクトルである。なお， 1950 年の 調查中はそれ以前の帰属が用いられていた。したがって,

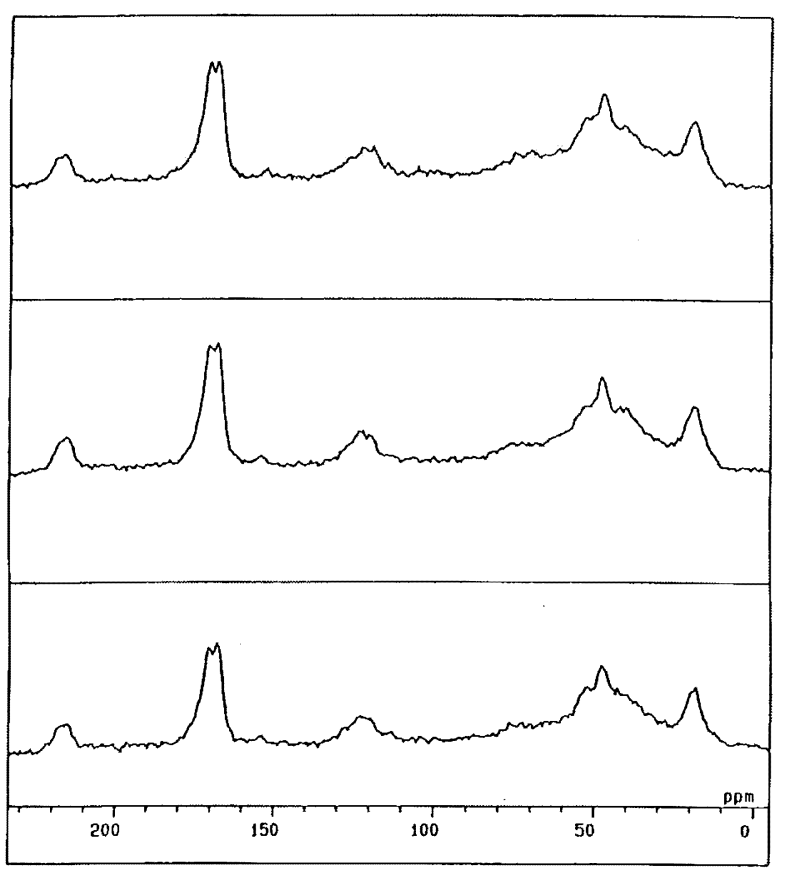

図 2 三つの棺の中にあった絹の ${ }^{13} \mathrm{C}$ 固体高分解能 $\mathrm{NMR}$ ス ペクトル7)

上：清衡，中：基衡，下：秀衡の棺の絹

たとえば，基衡というのは須弥檀から見て左側の檀の棺を 指す。「高分解能」というのは, 誰かが個人的な基準から見 て，分解能が高いあのというような恣意的なあのではな い。NMR スペクトルの横軸を記述するパラメーターであ る化学シフトやスピン結合による分裂が観測できる装置で 観測したあのが高分解能 NMR である。図 2 は溶液の NMR スペクトルに比べると, 分解能は決して高くない。 でも,これは間違いなく固体試料に対する高分解能のスペ クトルである。それはさておき, $170 \mathrm{ppm}$ 近傍に見られる ピークはペプチド結合のカルボニル炭素からのあのであ る。二つのピークが重なっていることがわかる。低磁場側 からアラニン残基, グリシン残基に州属される。フィブロ インには，これら 2 種類のアミノ酸残基以外のあのあある が，分解能が不十分で（ちなみに，図 2 は $125 \mathrm{MHz}$ で測 定したものである), 他の残基からのピークは, 主としてア ラニン残基のピークの裾に隠れている。以下，アラニン残 基など, グリシン残基と呼ぶことにする。両ピークの相対 強度は三つの棺でわずかながら異なる。

古い時代の絹に関する自然科学的研究では布目順郎 優れた研究がある。それによると, フィラメントの幾何学 パラメーターは気温の影響を大きく受ける。事実, 上で求 めたモル分率は布目が導入した二つの幾何学的パラメー ターである断面積とあ断面完全度（断面がごれだけ真円に 近いかを表す指標）とあよい相関がある。そこで, 飼育温 度を変えて, 蚎を飼育し, 絹糸腺の各アミノ酸残基の分率 の飼育温度依存性を求める9 。これには長所と短所がある。 長所は絹糸腺は臭化リチウム水溶液に可溶のため, 溶液の NMR が測れることである。セリン, チロシン, バリン残基 
(a)

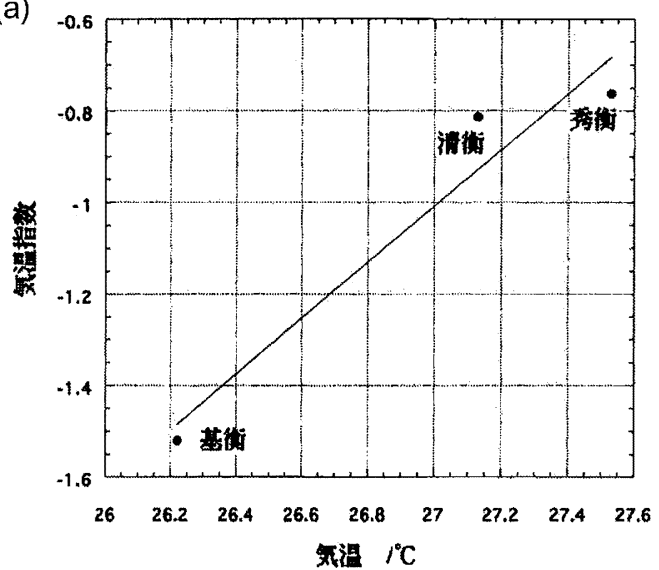

(b)

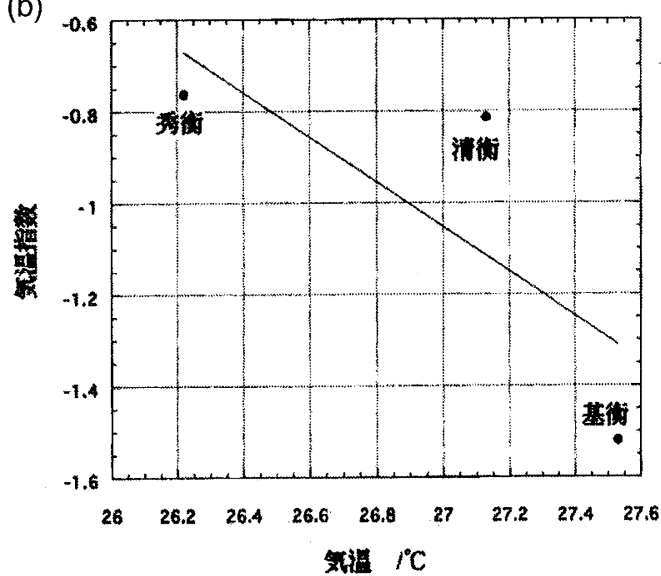

図 3 年輪考古学から得られた気温指数と蚕の飼育から推定される棺内絹に用いられた㡀の飼育温度推定值との相関 ${ }^{13)}$ (a): 1950 年以前の帰属に従った場合，(b): 現在，中尊寺が固執している帰属に従った場合.

のピークあ観測できる。各アミノ酸残基と書いたのはその ためである。短所はかつての虫室の平均温度と, コント ロールされた飼育器の温度は必ずしも同じではないことで ある。したがって, 飼育器の温度=気温とはならない。で も，順序についてなら期待できそうである。分析化学には 定性分析之定量分析之がある。その筆法をあってすれば, 定序分析ができそうである。棺の中の絹のグリシン残基の モル分率と絹糸腺のそれ（春嶺 1 号 $\times$ 鐘月 1 号を使用）上 が等しくなる温度を飼育温度と定義する。これはかつての 本当の飼育温度と定序的に関係づけられる。図 3 の横軸の 飼育温度はこれを指す。

一方，当時の環境を表す指標としてヒノキの年輪があ $3^{10)}$ 。年輪と年代を結びつける研究は年輪考古学として, 多くの有用な情報が得られている ${ }^{11)}$ 。年輪は，暑い夏には 成長が速いため組織が疎で，冬は密になると言われている が，実態はむっと複雑で，当該年だけでなく，過去の気温 の影響も受ける。しかも，前年， 3 年前， 4 年前の気温とは 負の相関があるなど, 一筋縄ではいかない。現在, 10 年前 までの気温までを考慮した相関方程式が得られている。こ の方程式を逆に解いて，当時の気温を推定することができ る。 5 年前までの気温の関数として求めたのが，図 3 の縦 軸の気温指数である7)。

図 3 の (a) は 1950 年以前, (b) は 1950 年以降の帰属に 従ったプロットである。つまり，(a) は須弥檀の側から見た 左右の定義，(b) は拝む人の側加見た定義に従ったもの である。この場合，いつの時点でつくられた絹であるかの 情報が必要であるが，それを教えてくれるものは何もな い。それで，没年に作られたすのと仮定する。清衡は 1128 （大治 3）年，秀衡は1187（文治 3）年に亡くなってい る ${ }^{12)}$ 。基衡は 1157 (保元 2) 年頃とされているが，「頃」を 省略， 1157 年没とする。これら 3 点の相関係数は前者が 0.97 , 後者が 0.77 であり, 前者に用いた帰属が妥当である ことを示している。

通常の自然科学や工学の研究では, 測定点が 3 点しかな
いのに，それから結論めいたことは言わないのが普通であ る。しかし，この場合は遺体が三体しかないので，これ以 上測定点を増やせない。文献 2,3 の書名には，それぞれ， 藤原四代, 藤原五代の語が見える。清衡, 基衡, 秀衡は, それぞれ，先代の子供であり，四代というのは，これらの 3 人に秀衡の子供の泰衡を加えたものである。彼は源頼朝 の追討を受け，現在の秋田県で亡くなっており，中尊寺に は首級が届けられただけで，彼に関する絹製品はない。五 代というのは, 清衡の父親, 安倍経清を加えた言い方で, 平泉以前の人であり，彼に関する絹製品む残っていない。 したがって，図 3 の補強には別の方法が必要である。

図 2 の最右翼, $20 \mathrm{ppm}$ 近傍に他のピークとは重なって いないと考えられるピークが観測される。アラニン残基の $\mathrm{C}_{\beta}$ からのピークである。これのスピン格子緩和時間は粘 弾性の推定に役立つ。ただし，これには二つの準備が必要 である。まず，スピン格子緩和時間が製造当時の物性を反 映していることのチェックである。何分にあ古い時代の試 料なので, 劣化が進んでいる。劣化している部分が限られ ており，そこに応力集中を生じているためボロボロになる のであれば，平均としては，現在であ製造当時の物性が保 たれていると期待できる。これはフレッシュな試料とそれ に電子線照射してボロボロになった試料とのスピン格子緩 和時間の比較から，製造当時の物性が保たれていることが わかっている ${ }^{13)}$ 。次に，常磁性緩和の影響を受けていない ことのチェックが必要である。緩和時間は核の双極子一双 極子相互作用による場合に限り, 分子運動を反映するから である。染色された絹製品には染料と一緒に媒染剂が使わ れている。これには Feイオンのような常磁性イオンを含 むものがある。これも, フレッシュな試料とそれを染色し たものとの比較により, 通常の染色条件であれば無視でき ることがわかっている。どちらも，この展望の趣旨からは ずれるので，これ以上の詳細は述べない。このような チェックの後, スピン格子緩和時間を横軸にとり, 図 3 と 同様のプロットをすると, 相関係数として, (a) では 0.94 , 
(b) では 0.26 が得られ，やはり須弥檀の側からの左右の定 義が正しいことがわかる。つまり，1950 年の M 博士によ る定義の逆転は誤りであったことがわかる。これを急いで 訂正しておかないと，世界遺産登録後だと世間の注目が大 きくなり，中尊寺や文化庁が恥をかくことになる。

1 節で高分子科学の手法を用いた解析という表現を用い た。これは絹という高分子を対象にした研究ということで はない。グリシン残基のモル分率という確率論的概念やス ピン格子緩和時間という非平衡系の統計力学的概念を用い たということである。横軸に周波数（通常は ppm 単位に 無名数化されている), 縦軸に強度をとった NMR スペク トルを例によって考えてみよう。有機化学だと, 得られた 化合物の同定にとって重要なのは, 化学シフトや結合定数 といった横軸に関するパラメーターである。それに対し て, 高分子科学では, 立体規則性や共重合組成などを求め るのに重要なのは，相対強度という縦軸に関するパラメー ターである。確率論と大袈裟に構えるほどのことではない が, 決定論的科学に馴れている人にとっては, 意外に難し いらしい。あえて説明を加えておく。非平衡系の統計力学 については, 説明は不要であろう。

\section{4. 他の分野からの寄与}

左右の定義に関する高分子科学的, あるいは分光学的ア プローチはほかに見当たらない。しかし，他の分野からは 多くのアプローチが見られる。理科系, 文科系, それぞれ, 一つずつ紹介しよう。

理科系の代表として, 埴原和郎の人類学的研究があ る $^{14)}$ 。本論に入る前に, この文献の来歴について述べてお く。中尊寺之朝日新聞文化事業団の調査が行われたのが 1950 年であるのはすでに述べたと抢りである。その後, 各委員により, 謄写版刷りの最終報告書が書かれていた が, 長らくその存在が忘れられていたのが, ようやく 1994 年になってまとめて, 立派な装丁で出版されたのが 文献 4 である。文献 14 は 1994 年の出版の際, 埴原に よって加筆されたもので, 同じ巻にまとめられているすの の，他の執筆者によるむのとは性格を異にする。埴原は 3 遺体の頭骨を計測し, 類似度係数 ( $Q$ 相関係数) を求め, 清 衡からの距離が（定義変更前の）基衡 0.645, 秀衡 0.750 , 泰衡 0.875 であることから, 変更前の定義でいいとしてい る。その他にも, いくつかの計測をし, 変更前でよいか, どちらとも言えないという結果を得ている。しかし，父·子 が必ずしも祖父・孫より類似性が強いという保証がないと 慎重である。

文科系の代表として, 加島勝の工芸意匠からの考察があ る $^{15)}$ 。工芸意匠の時間的流れとして, 中央檀 $\rightarrow$ 西北檀 $\rightarrow$ 西 南檀が見られると結論している。西北檀, 西南檀というの は, それぞれ，須弥檀の側から見て，左，右のことである。
また, これらより以前の多くの研究を総括して, 現在の 定義に疑義を挟んだ大矢邦宣の論文むある ${ }^{16) 。 い す ゙ れ に し ~}$ ても，いずれも 1950 年の定義の逆転を䛊りとするものば かりで, ここで紹介した高分子科学的研究は, 曖昧さを伴 わない形で，それまでの理科的，文科的研究を支持したも のと言えよう。研究というのは，今までに得られていな かった結論を得て, 初めてその価值を生ずるあのである。 ということは, 1950 年の定義でよいという結論に達した 人は，それを論文にしていない可能性がある。その分は割 り引いておく必要があるかもしれない。

\section{5. 中尊寺および中尊寺側の対応}

読者は仏門に帰依している人は人格高潔と思っているか力 もしれない。それが正しいかどうか, 以下を読んで判断し て欲しい。

「旧石器発掘ねつ造」という大見だしで, 宮城県上高森遺 跡の発見が捏造であると毎日新聞に報ぜられたのは 2000 年 11 月 5 日のことである17)。それまでにも次々に新しい 旧石器時代の遺跡を発掘し, 神の手をもつ考古学者と言わ れていた F 氏の自作自演の捏造であったという記事であ る。考古学界では上を下への大騒ぎになり, その後, 他の 新聞であ報ぜられたので，憶えている読者も多いことと思 う。いくつかの理由加, 筆者は F 氏の発掘は疑わしいと 思っていたので, 捏造自体には驚かなかった。それまでの F 氏の発掘は, 回を追うに従って, だんだん古い時代へと さかのぼっていく。そんなに都合よく, 発掘対象が時間よ ともに線形的に古くなるはずはない。前のあのより古いも のでないと，世間の耳目を集めることはできないと考えた 作為の結果であるのは明白であると考えていたからであ る。理由を列挙することはこの展望の目的から離れるの で，これ一つだけを指摘するにとどめたい。では，筆者は まったく驚かなかったのか？いや，驚いた。しかし，そ れは別のことによる。 F 氏の上司に当たる人物の, 彼に騙 されたという談話が掲載されていたことである。人名が はっきりすることは筆者の意とするところではないので, 文献の引用を省略するが，F 氏が発掘した遺跡からの出土 品之称する屯のの理化学的解析の結果が, ある理科系の学 術雑誌に公表されている。そこには，F 氏も上司氏む共著 者として名を連的ている。私どあのコミュニティーでは, 論文に名を連稀ることは，その内容に全責任をもつという ことである。つまり，上司氏は加害者である。にあかかわ らず，被害者面をしている。このことに驚いたのである。

高分子学会の会員の研究もだんだん学際化され, 異分野 の研究者との共同研究の段階で, パートナーとの文化の違 いに戸惑いを感じることも多いと思うが，理科系どうしだ と, これほよ゙のカルチャーショックは感じていないであろ う。文科系になると，ほかにも都合の悪い研究は抹殺する 
というのがある。中尊寺の遺体の左右の誤認についての NMR による研究がマスコミで記事になったのは1999 年 5 月が最初である。いくつかの新聞で採り上げられたが, 読売新聞岩手版があっとあ詳しい18)。そこには中尊寺側 の，NMR だけで決まるものではないというコメントが出 ている。ポパー19)を引用するまであなく，科学は反証可能 でなければならない。ここで紹介した研究は，自然科学的 であると否とを問わず，他の方法で反証可能であり，科学 の研究になっている。それに反して，中尊寺の態度は，た だ，それだけでは駄目というだけで，その後も何の反証も あげていない。これは 1950 年の誤認を認めたということ になる。にもかかわらず，世界遺産への登録を目前にして， 態度を改めようとしていない。

\section{6. 少子高齢化社会一結びに代えて}

少子高齢化社会之言われて久しい。筆者は 1992 年に国 立大学を定年退官し, 私立大学で 10 年間, それまで, 研究 をしてきたことのない学生に，卒業研究を課しながら，自 らも研究を進めてきた。若い現役の研究者の邪魔をするこ となく, 自分の過去の蓄積を活汃して, 社会に貢献するの が高齢化社会での高齢研究者のライフスタイルであろう。 そこで筆者が選んだのが，考古学的対象の NMR やXPS などの機器による研究である。ここではその一つを紹介し た。ここで得られた成果あさることながら，高龄化社会の 研究例としてあ, 読んでいただければ幸いである。団塊の 世代のリタイヤーも目睷の間に迫っている。

\section{文献}

1) マルコ・ポーロ（愛宕松男訳注）：「東方見聞録 $2 」$,（東洋文庫 183, 平凡社), 1971, p. 130

2）遠山 崇：「奥州藤原四代一生る秘宝」，岩手日報社，1993

3) 大矢邦宣:「奥州藤原氏五代一みちのくが一つになった時代」, 河出書房新社，2001, p. 160

4) 中尊寺：「中尊寺御遺体学術調查最終報告書」，中尊寺，1994， p. 258

5) M. A. Becker, D. V. Mahoney, P. G. Lenhert, R. K. Eby, D. Kaplan, W. W. Adams: "Silk Polymers," ACS Symposium Ser. 544, 1993, p. 185

6) K. Mita, S. Ichimura, T. C. James: J. Mol. Evol., 38, 583 (1994)

7) R. Chujo, A. Shimaoka, K. Nagaoka, A. Kurata, M. Inoue Polymer, 37, 3693 (1996)

8）布目順郎：「絹の東伝」，小学館， 1988, p. 48

9）中條利一郎, 島岡 彰, 日下 健, 福田秀治, 笠井夕記子, 瀬 戸利津，鈴木 誠，奥村 一：文化財と探査，2,19 (1999)

10）田中 环, 光谷拓実, 佐藤忠信, 八嶋 厚：「年輪に歴史を読 む」，奈良国立文化財研究所， 1990, p. 63

11) 文献 9, p. 140

12) 文献 2, p. 284

13) R. Chujo, K. Fukutani, Y. Magoshi: "NMR Spectroscopy of Polymers in Solution and in the Solid State," ACS Symposium Ser. 834, 2002, p. 83

14) 文献 4, p. 449

15) 加島 勝: 東京国立博物館紀要, No. 30, 151 (1995)

16) 大矢邦宣：岩手史学研究，No. 70,118 (1987)

17) 毎日新聞東京版 2000 年 11 月 5 日

18）読売新聞岩手版 1999 年 5 月 16 日

19） K. A. ポパー著，大内義一，森 博訳：「科学的発見の論理 上」, 恒星社厚生閣, 1971, p. 49

\section{Cultural Properties and Polymer Science-The Case of Silk Fabrics Preserved with Mummies in Chusonji Temple}

Riichiro CHUJO

Prof. Emeritus, Teikyo Univ. of Sci. and Tech.

E-mail: chujor@ntu.ac.jp

Abstract: Chusonji temple was constructed in 12th century and is well known the preservation of three mummies of Fujiwara chieftains; they are Kiyohira (1st), Motohira (2nd), and Hidehira (3rd). According to an old document they are preserved under the floor of Konjikido (Golden Hall) in the order of the center, left, and right. The question is in whether the left and right are defined from the altar side or the prayers side. Carbon-13 solid state NMR has been applied to the silk fabrics which were preserved in the coffins of these three chieftains. Amino acid fractions were determined from the NMR and compared with the climate when the chieftains were died. The climate was estimated from dendrochronological data. Spin-lattice relaxation times of the fabrics have been compared with the climate. Both comparisons support the definition from the prayers side. This is consistent with the traditional definition in Oriental countries but contradicts with the definition adopted by the temple.

Keywords: Silk Fabrics/Chusonji Temple/NMR/Mole Fraction/Spin-Lattice Relaxation Time/Assignment of Mummies 